\title{
Globalisation: Its Exclusions of Poor and Black Populations ${ }^{2}$
}

This is part of the of Black Awareness Day and the Zumbi dos Palmares celebrations, at the José Bonifácio Cultural Centre in the city of Rio de Janeiro, where the first Kilunge Afro-Brazilian Book Fair was held on November 17th and 18th 1997. In addition to the launch of several new titles by Afro-descendant authors, or books specifically on the black issue, the poet Elisa Lucinda also participated in the event, and she presented her show entitled "The Similar".

Professor Milton Santos also gave a lecture at the event, in which he addressed contemporary issues of organisation and progress for the Afro-Brazilian community.

I'm very flattered by this invitation, and by the kindness of the Director of the José Bonifácio Cultural Center. First of all, for the pleasure of being able to visit this place, which is a perfect example of something that we have to protect. And secondly, for the pleasure of being able to speak here. When Hilton Cobra called me, I asked him, "What should I say?" Because I'm not an expert especially on the black or the race issue. I've not conducted systematic studies on the issue of race or blackness in Brazil, or anywhere else for that matter. So, I said to him, "Isn't it a mistake for you to invite me to speak here?" And he, with the kindness that he's well known for, insisted and convinced me to do it. So, what I'm going to present today is yet another testimony

\footnotetext{
'MILTON SANTOS was a Brazilian geographer and geography scholar who had a degree in law. He became known for his pioneering works in several branches of geography, notably urban development in developing countries.

2 This article was originally published in http://www.alternautas.net/blog/2020/11/4/globalisation-its-exclusions-of-poor-and-blackpopulations. This text has been translated by Nick Pope from the original reproduced in: SANTOS, Mílton. As exclusões da globalização: pobres e negros. Thoth, Brasília, n. 4, p. 147-160, 1998.
} 
from a black man, who has always lived knowing what it is to be a black man, but also with cautious and tempered ideas about what the problem actually is.

First of all, I'd like to caveat by saying that I consider myself to be an 'outsider' intellectual - something that's quite rare in Brazil. I don't belong to any party, I don't belong to any group (including any group of intellectuals), I don't subscribe to a particular creed, and I don't participate in any political militancy.

So, I wanted to start with a few questions: "What does it mean to be a citizen? What is it to be a full individual? Does being a middle-class mean being a citizen? What does it mean to be a citizen in Brazil?" And finally: "Are black people citizens?"

What does it mean to be a citizen? Citizenship is a slow, hard achievement. Citizenship is a concept originally produced in Europe, crafted over centuries, and which resulted in the creation of democracy and the establishment of each individual as a kind of natural and effective opponent of the State - the citizen -, supported by laws and a set of inalienable rights.

Forgiveness: democracy has never been fully achieved. What we saw by the end of the war until around about 30 years ago, was a quasi-democracy, within which quasicitizens lived.

This idea of citizenship arose, interestingly, at the same time that technical progress was being made in Europe, in turn, facilitating the expansion of capitalism. Thus, technical progress appears to be a threat to the individual's self-actualisation and fulfilment. It threatens fulfilment because, at the same time, philosophical ideas emerge that later transformed into political ideas and actions, on both sides of the Atlantic: these were the revolutions that took place in the United States, England, and France.

Countries like ours, Brazil, have never really understood or known the figure of the citizen. What we call here by that name makes a mockery of the idea of 'citizenship'. I prefer to insist on the fact that in Brazil, the recently expanded middle classes have never actually become citizens. The middle classes have always wanted to retain their privileges - and privilege is the enemy of citizenship - but the poor and all minorities have never even had rights. In such a way that the expansion of the middle class in Brazil turned out to be a condition for citizenship not to be created. Especially because the expansion of the middle class is parallel to the explosion of consumption and the replacement of the idea of the citizen by the idea of consumer. We can see today the joy, the contentment with which even apparently enlightened people praise the 
Consumer Code. The Consumer Code is an achievement, but it's an achievement that replaces the notion of citizenship. Now, consumption is an emollient, it's something that softens people, that imprisons them through old age, that summons them to fashion and a taste for objects, and that glorifies, not exactly principles, but results.

What I want to invoke by that is a particular history, like the one the Brazilian develops from the non-existence of citizenship. When it was possible for this idea of citizenship to assert itself, what happened was actually the complete opposite: that is, the affirmation of the idea of consumption and the desire to be a consumer, which is exceptionally large in Brazil. In developed countries, people consume, especially since the fifties, and in the United States a little earlier; but they also defend the position of the citizen, while defending themselves against this invasion of consumption. They would be less than perfect consumers, because in their search for a defence against consumption; whilst we are more than perfect consumers, because we do not defend ourselves against consumption. And consumption is the greatest fundamentalism in today's world, and it's certainly the greatest of them, since we are all reverent and obedient to consumption, much more than to any religion. It also brings with it difficulties in relation to the liberation of spirit and expansion of our consciousness.

It's because of this that it's difficult to create, in countries like this, full and complete individuals. Or strong individuals. But what makes a strong individual? A strong individual is someone who's strong within themselves, based on an understanding of what the whole is and what each person consists of in the face of the world; knowledge that the world is in motion, it's becoming, it's the future. The individual within the world must actively participate in the production of that future, recognising what destiny is. Now, this strong individual is embedded with an inherent contradicted in the way that they produce themselves in the world, because the production of consumerism is stronger.

The absence of strong individuals should be a fact of intellectual work, since the strong individual is necessarily critical - critical of himself, critical of the environment, critical of the history that is being made. This complete and full individual, or this strong individual, is in a position to produce democracy, because democracy is the permanent criticism. But there is a big difference between a strong individual and a citizen. The difference is that I can be a strong individual, as many who are here certainly were during the authoritarian regime. But they were not citizens, because citizenship needs laws, legislation, and a constitution that ensures 
that the strong individual is able to continue expanding their fortress, their completeness, and that ensure that society is made up of individuals who are given the rights that allow them to continue to be even stronger.

There's a difference, then, between being a strong individual and being a citizen. Being a strong individual is an everyday production repeated but also modified, since the history and life of each one of us takes place in a continually changing world. Therefore, through their exercise of criticality, that this individual has to be aware of the world on a daily basis in order to relate themselves to the rest of the world. I, myself, also have to change as a complete individual and as a strong individual. And that is how societies evolve and get better.

Now, under these conditions, being middle-class does not equate to being a citizen in the Brazilian case, even less so. I believe that one of the reasons for the backwardness of Brazilian politics, the difficulties we have in terms of political parties and forming coherent political agendas that add up to a national project, also comes from Brazil's history. Brazil's history of the consumer and its triumph whilst citizenship was defeated, consumption became victorious - and the fact that Brazilian political regimes, after the attempt to install democracy, were regimes commanded by the middle classes. This has meant that discussions about poverty in Brazil are residual. Poor populations even seem to appear, within a huge part of discourse on the left, as ornamental, as superficial, even as something decorative. There's no real concern for the poor, the oppressed, or minorities.

And who knows if this has something to do with the level of Brazilian intellectuality, or not. Because being an intellectual is, or should be, primarily, to do with worrying about those below. It's evident that being intellectual also means there's a willingness to see things in full, as a whole, in such a way that both the "Baghdad" of the powerful as the "Baghdad" of the poor was not from the intellectual's time. ${ }^{3}$ The intellectual emerges from the era of making sense of society as a whole, and from there they take sides with the poor. But defence of the poor cannot precede understanding society as a whole, because otherwise this thinking would not be effective. From a political point of view, it would provoke a general breakdown within society. My criticism is based on knowledge of the way that society moves as a whole.

\footnotetext{
${ }^{3}$ Although the translation is not clear, 'Bagdã' (Baghdad) is typically used to refer to something far away.
} 
For Brazil, I'll repeat, there are no citizens, since those who could be citizens due to their education, don't even want to be. There must be some middle-class people in this room who certainly don't behave in this way, but who have seen the behaviour of relatives or of the middle-class as a whole, that fully accept the idea of presenting themselves to a public office with a letter or a phone call. Whoever goes to a hospital, to a health clinic, without saying first to the hospital administrator, the doctor, or the employee: "Look at the name on the stamp there. So and so is my cousin". One of the biggest problems for blacks in Brazil is that black cousins do not have someone important they can call.

Blacks are oppressed, not only in this society as it's been built, but in the society of how it can be built. Starting from this central idea, I want to point out some things that we should think about. It could start with a list of situations that reflect the type of citizenship of blacks: of job opportunities, of lower pay, of unemployment itself, of the same opportunities for social, economic and professional advancement. Blacks also removed and relocated, put in a lower position within the typology of space, blacks also discriminated against in flows and circulations from the national to the urban level, not only because of the price of movement, but because of the opportunities available to blacks in each location. Because my location in the country or in the city has to do with the price of displacement, and blacks, living in criminalised places, have difficulties in ascending to places that they are excluded from and prohibited from entering.

It is curious to hear, even today, that education is a way out for blacks and the poor, when we know that education, through its very core, is unequal, the educational system is unequal. So, they say to us: "Let's study, let's improve", and point out: "Look at Dr. So-and-so, he studied and improved". The reality is nothing like that! If Dr. So-and-so studied, or improved, then it's chance, or a set of social conditions that allowed him to do so, but not through the educational process. The solution is not in education. And health? It's a shame in Brazil. An medical field dominated by elites, which has contempt for men and, in the case of blacks, treats them as things instead of humans.

But all of that has already been said before and written about, and I don't know why it continued to be part of the black discourse. What I mean to say is that the discourse is no longer effective. We must invent other, more imaginative discourses, closer to contemporary history, more effectively, with more force, because asking a society that has been desensitised for centuries - and that is becoming increasingly insensitive 
with the expansion of the idea of consumption - that is sensitive to a part of the population considered naturally inferior. I believe that this is a waste of time and it is the wrong political path.

Perhaps we should remember other things in the world today, such as these new rights that have been created through the information age, such as copyright and the right to exercise individuality. I believe that this is also a problem, in what many see as a lack of esteem. What really exists is an inexistence of a right to exercise individuality. Artists discovered this long before university scholars. In fact, the academy is becoming less and less capable of producing a thought, incompetent to take care of anything, such as minorities or poor people. It's increasingly repetitive and lacking. It would have to look towards the spontaneous movement from those below it for inspiration to give new energy to its work.

I won't cite numbers either, as I am convinced that this is worth very little. So, I brought with me a statistical series. These series are very frequent in master's and doctoral theses. But they don't do anything, if I'm not able to give each column a historical value, and each column inserts a different historical reality. But I use the series quietly in my work. We all do. That's how we promote ourselves, that's how we get jobs at universities, that's how we become known and, sometimes, famous. But what can I do with a series of statistics - for example, on the black question - in Brazil if I'm not able to interfere in history in concrete terms, not only of blacks separately, but of Brazilian society? It's not the time to use up our energy exhaustively on exclusive knowledge building around the black condition. Instead, it's time to take into account of black presence in relation to other presences in Brazil.

Racism, prejudice, discrimination. It's been the central topic of 40,000 different academic conferences. Now, I have to seriously question if I'm going to get stuck in this grammatical discussion between what is preconception, discrimination or racism, and their differences - rivers of ink have been spent on these topics, and the university smiled happily whilst reading this literature - so, what more can I do with this? What I want is for us to change things up, starting with my home, which is the academy, with its attitude towards this fundamental problem in Brazil. What I am going to propose now, and it will be the centre of what I am going to say next, is that what the issue is, it's 'sociality'. That is: how people live together in society, the ways of living together, the sociability to run alongside this 'sociality', which is also shown through territory, through space. 
When we arrive in this space, we are not only faced with houses that look similar, but we should wonder about what sociability and what 'sociality' exists within these houses between people. So, I would propose three basic data so that we can study this question. I said that I am not an expert. I am not an anthropologist. I do not have adequate training cast these ideas. But what I am reflecting on is my experience, which is also the experience of others, because no one lives in isolation. So, there would be three basic data sets that allow us to work on this issue. A basic data is what I am calling 'corporation', another is what I am calling 'individuality', and the third is what we call 'citizenship'. What exactly do we seek to define by introducing these words? 'Corporation' is made up of objective data, 'individuality' of subjective data, 'citizenship' of political data.

Sorry to mention my personal case now. But I have a high level of education and I can give a lecture like this. For this reason, I imagine that I'm a strong individual, but I'm sure that in this country I'm not a complete citizen. I cannot be a citizen if I'm not treated like a citizen, and if I'm not treated like a citizen, I'll rarely be treated as a strong individual.

Social formation was put forward in an incomplete way by Marx, perfected by Lenin, put to bed by the Communist Party of Soviet Union, and then reborn again through the studies of Italian and French, and some Latin American Marxists, notably from the northern part of South America. Because at that time, when Marxism was a fashionable way of thinking, Mexico was not so powerful - and Mexico is in North America. And these scholars were in Mexico and Venezuela. Socio-economic formation studied the way each country developed from its territory, its economic, social, cultural history - but also without forgetting international relations, studied alongside and incorporating references of time, or, the world. The dated world, not the world taken blindly. A dated world, because the world is the reason for what is done in each place and in each time.

Even so, we were hampered in the analysis of Brazil's reality, because Brazilian Marxism is a Marxism of the mode of production, and not of social formation. The mode of production is a historical reality, but it is not a geographical reality. Geographical reality is economic and social formation. The theories that in Latin America and Brazil tried to explain the Latin American and Brazilian reality, such as the infamous dependency theory, are theories about the mode of production, and not about social formation. So the analysis should be done in three stages: the past, as an inheritance; the present, as the situation; and the future, as a perspective. 
In a country like Brazil, our inheritance means that we have a civic model that is subordinate to the economic model. It has always been like that. At all times, the economic model subordinates the civic model. Just look at the crises of the Brazilian economy and the slogans coming from the top-down, stating that those who do not agree are unpatriotic; and this is even echoed by the opposition. Here we see the weight carried by the economic model, as opposed to the civic model. I believe that the history of blacks would have a lot to benefit from if it were rewritten from the lens of the civic model.

The subalternity of the civic model has, for example, meant that the debate around pensions in Brazil has been neglected, similarly around the debate on public services. This debate has become impoverished in Brazil because old people are asked to take care of themselves, and society just accepts this heinous demand, facilitating the installation among us of the project according to which Brazilians will quietly watch a genocide of the population - because it is what is happening. The programmed abandonment of the old, the programmed abandonment of the poor, the programmed abandonment of the blacks are three genocides that are part of the current political process and for which the voices of the opposition parties are practically absent, because they accept the debate in terms of what is handed to them.

That's why discussions about the poor, minorities, blacks become fragmented. I no longer speak of women, because women fight within the dominant social class. That is not the case for blacks and I do not accept this comparison between the two. Women have made tremendous progress, which has been well deserved. But the struggle they now have is within the ruling class. Blacks don't even have the means to fight, they do it from outside the ruling class. Then the press and certain types of intellectuals come to talk to us about minorities. But there's no such thing. There are different minorities that must be studied in light of our history.

All of this is frustrated today because of market democracy. The threat is that all these differences will widen. Because of this, blacks should not wait for the possibility of a return to growth in Brazil. If Brazil grows again, blacks will be in an even worse position: on the one hand, because they don't have connections and someone to call, and this is one of the central facts in Brazilian society today; worse still, because they don't have access to education in order to prepare themselves for the world as it's changing; and worse still, and above all, because the world that is emerging doesn't concern itself with the welfare of society as a whole, but it prefers to focus itself in certain parts of society and it disaffects others through advertising. 
I'll now speak of another element central to Brazilian society, which, incidentally, is a common fact throughout the world, but which in Brazil, for the reasons I mentioned, acquires enormous importance. I'm speaking about the death of politics. Nowadays, it's not governments who do politics; it's done by the big companies. They decide on public budgets, how they are structured and how they are used. At all levels: at the federal level, at the state level and at the municipal level. Just look at this battle between the municipalities to attract large companies to their territories, who have the effect of disorganising life in each place they come to. They disorganise in every way possible. First, because they arrive demanding tax breaks and incentives, and, when they eventually do settle, they force a transformation in the nature of 'sociality', to labour structures that work for them, but that crush the labour structures based around local culture, local territory, local history. They look for an indispensable order so that they can achieve their prosperity, and they create disorder around everything else. That's why Brazil has become an ungovernable country. That's why our cities are no longer governed. This ungovernable status came precisely from the fact that politics is no longer done by politicians, nor of the State, but it is done by large companies.

Luckily, there is another place where politics is also done in Brazil. And to be sure, it's not in the middle class, even though every day we keep looking for it to comfort ourselves, forgetting that we rhetorically say the complete opposite - from our collective concerns. Politics is made by the poor. The poor make politics every day, and this is one of the great fortunes of Brazil, and this will be amplified when intellectuals realise they should be concerned with the poor populations of this country.

This death of politics is clearly demonstrated by the fact that elections are not a democratic exercise, but a place of electoral consumption. In such a way that candidates who have money to campaign, do so. It's marketing, but there's no strategy. So, that the polis appears as a market and the here and now is devoid of strategy. This is a general phenomenon worldwide, but it is acute in countries such as Brazil. This is compounded by the fact that geopolitics has ceased to be a fact of generals and diplomats, but has been entrusted to economists and advertisers. It's because of this that the individual is weakened in this atmosphere dominated by the market. And the recession, which appears to be a remedy to solve various crises, is by its very nature a source of increasing inequalities, in which the weakest in society are put in an even more vulnerable positions. 
I have been thinking that, in the current world, making progress in how we produce consciousness will occur because of the expansion of organisations, but also from disorganised protests. These organisations, in one way or another, are limiting movement. Organisations, by their definition, put a brake on innovation, as the organisation begins by electing its leaders, whose behaviour at one time or another differs from the behaviour of those they lead. In such a way that I imagine - and this is a proposal of conversation with blacks in Brazil - if there would be no reason to, at the same time, stimulate organisations, because it is essential to do this, but also to classify them, because organisational behaviour is closely linked to the way they composed. On the other hand, to see how blacks, in addition to black movements, which are not the same thing, move, or would like to move. Obviously the answers will be different in cities like Salvador, Rio de Janeiro, São Paulo, Belo Horizonte, but I believe that this is important to remember.

It's also important to remind ourselves that a good number of black organisations in Brazil are linked to the State machinery, and there is difficulty in managing them; while others are propelled by institutions that have a global view of the world. I refer clearly to, and I won't beat around the bush, to all organisations subsidised by the Ford Foundation and those that act in unison with them. I'm analysing them, and I'm not going to refer to any of them in particular, mainly because I don't know them well.

I also want to refer to a certain tendency of a certain leadership to try and be included as an individual in the middle classes. To be sure, his own inclusion in a part of society that, by definition, is not concerned with the production of his own conscience, and that, therefore, is a diversion from the central objective. I'm saying this to insist on the need to incorporate into our intellectual work, which is the only think that I can do - and I would like this to be done by even more people -, the understanding of what Brazil is, and what blackness in Brazil is. I don't believe that the comparisons, now so strongly made in relation to other anti-black countries, are valuable. What are the lessons I have from South Africa? What are the lessons I have from the USA? Undoubtedly I'm uneasy about the historical perspective, and it would be better if the result of this analysis could be replicated in how politics is conducted. But politics can only be done based on a Brazilian reality, because we are, first of all, Brazilian. Africa is a reference, but we are not Africans. North America is a reference, but we will not repeat its history. The history in which we situate ourselves and which we are going to remake, is the history of Brazil. 
I believe that the invitation to do it differently is part of a diversionist agenda, that is to say that it reduces the knowledge of the problem and it produces a few more authors, who are paid trips to attend these famous international conferences that are expensive and useless. It's the reason why I didn't accept being here in this meeting that has brought together so many of our comrades, and it's why I refused to participate as an important member of the committee of this organisation that was established a year ago in the United States, bringing together eminent figures from Brazil, South Africa, and the United States, to produce another book. [Reference to the Seminar Overcoming Racism - Brazil, South Africa and the United States in the 21st Century, held in Rio de Janeiro from 2 to 4 September 1997. (NE)]

It's about a process for making flower water that we all know so well within this country, and that is now done outside of it. I understand that people agree to participate in these things, because they are offered an opportunity to contribute, to get to know the global issue better, but there should be no illusion about it. When they invited me to be a part of this, I told them: "Now, I know how it works today together with international relations. I know perfectly well how things are organised at the international level, especially in the postmodern period, when people who think differently are invited to speak. The person comes and speaks. However, the vast majority of those attending want something else, but they still clap, because it is part of postmodernity, while resources continue to go to organisations that reproduce whatever central intelligence decides". So I said to them, "Would you give me the means to be able to talk to the black movements? Would I have any participation in organising the meeting to be held in Brazil in September?" "No, you can't do that! We want you side by side. At most, we publish an article of yours...”. I really don't need that anymore. But this is one of the problems with the so-called globalisation of the Brazilian black struggle. There's globalisation of the black struggle, yes, but our central issue is the political issue, and everything we do has to be done in the direction of politics, because the solutions are there. The strong individual, endowed with conscience to be a citizen, needs politics. They are strong within themselves, but being strong in the face of society is conducted through politics, through the creation of laws that guarantee his strength.

Well, I'm going to stop here. I thank Milton Cobra for inviting me, I wanted to have this conversation a long time ago. I know it has displeased everyone, in one way or another, but it doesn't matter, that is my role. The intellectual is not a vaudeville artist, I didn't come here to show my legs, but to show my ideas and defend them. But 
I don't want to be right either. I'm not sure I'm right, but I have a duty to express what I believe, no matter what the cost. This is an opportunity that I longed for, this is my way of engagement. I am here today, and I will be at other times to discuss issues like this. Thank you very much. 